\title{
Chemical and nutritional changes in stored herring meal. 2*
}

\author{
BY C. H. LEA AND L. J. PARR \\ Low Temperature Research Station, Cambridge \\ AND K. J. CARPENTER \\ School of Agriculture, University of Cambridge \\ (Received 30 fuly 1959-Revised 23 October 1959)
}

In the first paper of this series (Lea, Parr \& Carpenter, I958) we reported the results of experiments on the effect of storage on the nutritive value of herring meal as a source of protein for chicks. Over a period of $2 \frac{1}{2}$ months' storage in air there was extensive oxidation of the lipids, but only a very small drop in 'available' lysine (lysine with a chemically reactive $\epsilon-\mathrm{NH}_{2}$ group) and no significant fall in feeding value for chicks under the experimental conditions used.

A further test has now been made with material stored for up to 12 months. The feeding trial was designed only to measure the value of proteins as supplements to diets under conditions in which lysine was the limiting amino-acid. At the same time, the opportunity has been taken to ascertain whether a meal in which extensive oxidation had occurred would be more or less likely to cause tainting of the meat and eggs than a fresh meal.

The earlier experiments had shown a small but definite fall ( $9 \%$ in 12 months) in the 'available' lysine content of meal containing oil and stored in air, a fall that did not occur either with defatted meal exposed to air or with meal containing oil and stored in nitrogen. A reasonable hypothesis to explain this result would be that of a reaction between oxidation products of the oil, particularly carbonylic compounds (which could be either volatile fragments of the fatty-acid chains or non-volatile glycerides) and the $\epsilon-\mathrm{NH}_{2}$ groups of the lysine side-chains in the protein molecules.

Further evidence for or against this view has been sought in several ways. In one approach propanal, known to be one of the volatile carbonylic oxidation products of fish oils, was caused to react with fish muscle in the 'dry' state and the effects on free amino nitrogen, available lysine and nutritive value were measured. Attempts were made also to measure the interaction between oxidized fat and protein by procedures less open to question than the usual determination of decrease in solvent-extractable fat.

However, all of our experimentally stored and oxidized meals were still much superior as a source of protein, and specifically of lysine, to commercial meals that had been allowed to overheat badly during bulk storage. Another type of experiment was therefore made in which herring meal, either pre-oxidized or unoxidized, was heated in the absence of oxygen under conditions that might be expected to develop in the

* Paper no. г: Brit. F. Nutr. (1958), 12, 297. 
interior of an overheating pile. As the temperature was raised the oxidized meal at first showed increasing losses of available lysine whereas the unoxidized meal showed none, but at still higher temperatures both meals suffered heavy loss, and the difference between them became small. Obviously, at least two types of deterioration can occur, the oxidative type predominating during normal storage and mild heating, and the non-oxidative type during severe heating.

Finally, further observations have been made on the effects of several anti-oxidants in delaying oxidation of the oil in stored herring meal, and some degree of stabilization has been achieved in preliminary experiments by controlled preheating of the meal in the absence, or in the presence of a limited supply, of oxygen.

\section{EXPERIMENTAL}

\section{Preparation of the meal}

At the time of obtaining our sample of meal at the plant the quantity of herring available for processing was small and before conversion into meal the fish used had been preserved for up to 2 weeks by spraying with formaldehyde solution.

The herring were steam-cooked, pressed to remove most of the oil and aqueous 'stick' liquor and dehydrated by hot air in drying cylinders to about $30 \%$ moisture content. Drying was completed by exposure for a few seconds at $400^{\circ}$ in an 'Atritor'. 'The freshly ground meal was then transported in an insulated container packed with solid carbon dioxide to the laboratory, where it was gas-packed in oxygen-free nitrogen and stored at $-20^{\circ}$ until required.

The fresh meal (no. 3 ) contained $6.1 \%$ moisture, $66.2 \%$ crude protein, $12.5 \%$ ash and $\mathrm{II} \cdot 4^{-\mathrm{I}} 7 \cdot 4 \%$ extractable lipid depending on the method of solvent extraction used (see p. 95).

A few further investigations were also made on meals nos. I and 2 , described in the first paper (Lea et al. 1958).

Addition of anti-oxidants. Several portions of meal no. 3 were treated by spraying with anti-oxidants in solution in propylene glycol ( $1 \%$ of the meal) as previously described. Diphenyl-p-phenylenediamine (DPPD), which is very sparingly soluble in most solvents, was partly in suspension. Control samples for the anti-oxidant experiments were treated with propylene glycol only.

\section{Storage tests}

The larger samples of meal intended for use in feeding trials were stored at $20^{\circ}$ in cans with a relatively large head space periodically flushed with air to replace the oxygen absorbed. Control samples were stored in nitrogen at $-20^{\circ}$.

Meals stabilized with anti-oxidants. Two series of storage trials involving the use of anti-oxidants were made. In the first 2,6-di-t-butyl-4-methylphenol (BHT), with or without citric acid as synergist, was again used, but at concentrations now ranging from 0.005 to $0.05 \%$ in place of the single concentration $(0.005 \%)$ previously used. Tainting tests were made on one of the treated meals $(0.025 \% \mathrm{BHT}+0.01 \%$ citric acid) after storage for 4 months, and trials of nutritive value after 12 months. 
In the second series of experiments three other anti-oxidants, monobutylhydroquinone (MBHQ), DPPD and 6-ethoxy-2,2,4-trimethyl-1,2-dihydroquinoline (EMQ) were used, in addition to BHT, meals containing $0.025 \%$ of the inhibitor being stored at $20^{\circ}$ in flasks filled with oxygen and fitted with mercury manometers. The progress of the oxidation was followed by manometric measurement of the amount of oxygen absorbed, the oxygen used being replaced at intervals to prevent the development of any considerable negative pressure.

Meals stabilized by heat. In a third series of experiments portions of the fresh herring meal were submitted to various preheating treatments either: $(a)$ in sealed glass ampoules in presence of the very limited amount of air trapped between the particles and in the small head space above the meal, or $(b)$ in similar ampoules from which all air had been evacuated. The object of these procedures was to develop, if possible, anti-oxidant activity within the meal itself. The rates of oxidation of the treated meals were then determined manometrically in oxygen at $20^{\circ}$ as in the antioxidant experiments.

\section{Examination of the stored meals}

As before (Lea et al. 1958), the yield, iodine value and colour $\left(E_{1 \mathrm{~cm}}^{1 \%}\right.$ in chloroform solution at $400 \mathrm{~m} \mu$ ) of the oil extractable from the stored meals were determined at intervals. For measurement of colour the solutions were usually clarified with a little Celite (Johns Manville Co., London).

Determination of 'bound' lipid. For estimation of the amount of fat firmly bound to the protein, the stored meal was extracted exhaustively with boiling chloroformmethanol $(2: \mathrm{I}, \mathrm{v} / \mathrm{v})$ to remove free fat, and the insoluble residue hydrolysed with hydrochloric acid and extracted with diethyl ether to recover bound lipid.

Thiobarbituric acid (TBA) test. This test was also applied to the meals after various periods of extraction with chloroform-methanol, with the object of measuring empirically the quantity of one of the oxidation products of the fat (malonic dialdehyde) retained in combination with the protein. The method used for determining the TBA value was that of $\mathrm{Yu} \&$ Sinnhuber (1957) except that the pigment was extracted from the reaction mixture by means of the isoamyl alcohol-pyridine solvent of Schwartz \& Watts (1957).

\section{Effect of heat on herring meals}

Heat treatment. A quantity of the herring meal was oxidized by storage in air at $10^{\circ}$ for 98 days. The oxidized meal was then divided into six portions and heated in the absence of oxygen at $45,65,85,100$, I 55 and $130^{\circ}$ for $30 \mathrm{~h}$. For comparison, samples of the fresh herring meal were given the same heat treatments in the absence of oxygen and, at some of the lower temperatures, in air also, the relative humidity of the air over the meal being controlled to prevent desiccation.

Examination. In addition to measurement of the colours and available lysine contents of the meals themselves the lipid extractable from them was examined for yield, iodine value, colour and nitrogen content. Because the crude chloroform-methanol extracts from the more strongly heated meals contained greatly increased quantities 
of material insoluble or sparingly soluble in chloroform, both the crude and the 'purified' (chloroform-soluble) extracts from these meals were examined for yield and nitrogen content.

\section{Reaction of fish protein with propanal}

A sample of vacuum-dried cod fillets (E) similar to materials A and D used in an earlier study (Carpenter, Ellinger, Munro \& Rolfe, I957) had a moisture content of $4.0 \%$ and a pH, after reconstitution, of 6.65 . It was milled and equilibrated at $37^{\circ}$ with an atmosphere at $70 \%$ relative humidity to raise its moisture content to a level (I6.3\%) more favourable for a reaction between protein amino and aldehyde groups (Lea \& Hannan, 1949). Propanal (two equivalents, based on the free $\mathrm{NH}_{2}$ content of the fillets) was then added and the reaction followed at 15,37 and $60^{\circ}$ by determination at suitable intervals of the remaining free amino groups by the Van Slyke procedure (Lea, I947-8). Unreacted propanal was determined, by titration of an ethanolic extract of the reaction mixture with hydroxylamine (Maltby \& Primavesi, 1949; Feuell \& Skellon, 1953).

In a second experiment 'available' lysine and the nutritive value of the protein were determined respectively by the chemical and chick-feeding methods (see below) on a larger quantity of the cod meal after it had been allowed to react with propanal for $48 \mathrm{~h}$ at $37^{\circ}$. The product $(\mathrm{F})$ was treated by aeration and evacuation to remove any unreacted aldehyde or odorous volatile products.

Three samples of imported herring meals from bulk silos in which there had been spontaneous heating were obtained from a commercial source and examined, together with a control sample which had not overheated. The overheated meals had a browner and slightly charred appearance compared with the grey-brown colour of the normal product.

\section{Determination of 'available' lysine}

The procedure used was a simplification of that of Bruno \& Carpenter (1957) used in the earlier work (Lea et al. 1958). The water-soluble colour after acidhydrolysis of the DNP-protein was measured directly in $\mathrm{N}-\mathrm{HCl}$, without the preliminary digestion with methoxycarbonyl chloride to convert $\epsilon$-DNP-lysine into an ether-soluble derivative. It is now realized that the use of this reagent, though removing some interfering colour that remains water-soluble, does give a further source of interference from a histidine derivative (Carpenter, Jones \& Mason, 1959). With herring meals the original and modified procedures give almost identical values and a few more detailed estimations indicated that $92-94 \%$ of the colour measured comes from the lysine derivative with both fresh and stored materials. Since, in any event, one may expect approximately an $8 \%$ loss of DNP-lysine during the acid-hydrolysis stage no correction was made to the figures as obtained. The results are expressed as $\mathrm{g} / \mathrm{I} 6 \mathrm{~g}$ total $\mathrm{N}$ in the meals.

\section{Feeding tests}

Chick assay for lysine. The general conditions used (see Table 9) were similar to those described for test $\mathrm{I}$ in the earlier paper (Lea et al. 1958). The test materials were 
added to a lysine-deficient basal mixture and the compositions of the mix differed only slightly from that used earlier.

The basal mixture consisted of sesame-seed meal 5o, grass meal 5 , ground oat husks 5, arachis oil 6.9, Drivite A and D (Boots Ltd, Nottingham, containing 1000 i.u. vitamin $A$ and 200 i.u. vitamin $D_{3} / g$ ) 0.5 , oxytetracycline supplement (TM-5, Pfizer Ltd, Folkestone, Kent, containing $2.2 \%$ oxytetracycline) 0.07 , BHT 0.01 , together with the minerals and vitamins as already listed (Lea et al. 1958) to make a total of 70.3 parts.

The negative control diet (no. I, Table 9) was then made up to contain 70.3 parts of basal mix and 29.7 parts of maize starch. The remaining diets were similar but with supplements added at the expense of starch, as shown in Table 9. It had been intended that the only supplements to diets 2 and 3 would be 0.18 and $0.36 \%$, respectively, of L-lysine monohydrochloride. Unfortunately, too little starch was added to these diets in mixing them, so that in effect they contained an extra $9 \%$ of basal ingredients and a higher proportion of lysine. However, they were still useful as indicating the response that can be obtained from supplementation with a high level of lysine.

In diets 4-7 the same level of each type of herring meal was used, and they also contributed almost exactly equal amounts of crude protein.

\section{Palatability tests}

Twelve Rhode Island Red $\times$ Light Sussex hens kept in battery cages were allotted at random to four experimental diets, each made up of coarse ground wheat 25, middlings 25, $\mathrm{CaCO}_{3} 3, \mathrm{CaHPO}_{4} \cdot 2 \mathrm{H}_{2} \mathrm{O}_{1} \cdot \mathrm{I}, \mathrm{NaCl} 0.25$, Drivite $\mathrm{A}$ and $\mathrm{D} 0.25$, either herring meal $\mathrm{A}, \mathrm{B}$, or $\mathrm{C}$ (see Table 10 ) or groundnut meal 8 , and ground barley to 100 .

Eggs. The diets were given for 2 months and the eggs tasted eleven times. During the Ist month egg yolks from three hens on each diet were mixed and sampled for tasting; during the and month one bird only on each diet was available. Each of the four panel members was provided with a set of flat-bottomed specimen tubes $(3 \times \mathrm{I}$ in.) containing the samples under test, which he immersed in water at $60^{\circ}$ for 2 min. He then tasted the contents, grading them according to a simple four-point scale. In addition, on several occasions surplus eggs were lightly boiled and tasted in the usual way.

Meat. After $\mathrm{I}$ and 2 months hens were killed and one from each group was roasted without addition of fat. The skin and the light and dark meat were tasted by a panel of four. Portions of the light and dark meat were also tasted after steaming.

\section{RESULTS}

\section{Chemical tests}

Oil content of the meal. Continuous extraction of the fresh meal with light petroleum (b.p. $40-60^{\circ}$ ) under reflux gave $11 \cdot 4,1 \mathrm{r} \cdot 8,1 \mathrm{x} \cdot 9$ and $12 \cdot \mathrm{s} \%$ lipid after $\mathrm{I}, 3,6$ and $\mathrm{x} 6 \mathrm{~h}$. With diethyl ether the $16 \mathrm{~h}$ figure was $12 \cdot 6 \%$. Much larger quantities of lipid were extractable by chloroform-methanol but the crude extract contained a considerable 
amount of non-lipid material, particularly when the $\mathrm{I}: \mathrm{I}$ solvent mixture was used, and required purification by solution in dry chloroform (Table $\mathrm{I}$ ).

One of two procedures was used. In some experiments a single extraction at room temperature for $3 \mathrm{~h}$ with chloroform-methanol $(2: \mathrm{x})$ followed by re-solution in chloroform was used, yielding about $9 \mathrm{r} \%$ of the total lipid extractable with this solvent (Table $\mathrm{I}$ ). In others extraction for $\mathrm{I} h$ under reflux with the same solvent gave an almost quantitative recovery of oil. The colours and iodine values of the oils extracted from fresh meal by the two methods were not appreciably different, but the oxidized oils may have undergone some slight further change during hot extraction.

Changes in the stored meal. A few of the chemical values obtained for the stored meals, including those used in the experiments on nutritive value and tainting, are

Table I. Lipid extractable from fresh herring meal no. 3 by chloroform-methanol

\begin{tabular}{|c|c|c|c|c|c|}
\hline \multicolumn{2}{|c|}{ Chloroform-methanol } & \multirow[b]{2}{*}{$\begin{array}{l}\text { Conditions of } \\
\text { extraction }\end{array}$} & \multirow[b]{2}{*}{$\begin{array}{l}\text { Time } \\
\text { (h) }\end{array}$} & \multicolumn{2}{|c|}{$\begin{array}{l}\text { Lipid extracted } \\
\text { (\% of meal) }\end{array}$} \\
\hline $\begin{array}{l}\text { Proportions } \\
\text { (v/v) }\end{array}$ & $\mathrm{ml} / \mathrm{g}$ meal & & & Crude & Purified* \\
\hline $\mathbf{I}: \mathbf{I}$ & 10 & Room temperature & I & $15 \cdot 4$ & $14 \cdot 5$ \\
\hline $2: 1$ & 10 & Room temperature & $\begin{array}{l}1 \times 0.5 \\
2 \times 0.5 \\
3 \times 0.5 \\
4 \times 0.5\end{array}$ & $\begin{array}{l}12 \cdot 9 \\
15 \cdot 9 \\
16 \cdot 4 \\
16 \cdot 6\end{array}$ & $\begin{array}{l}12 \cdot 7 \\
15.4 \\
15.7 \\
15.8\end{array}$ \\
\hline $2: 1$ & 25 & Room temperature & 3 & $16 \cdot 6$ & $\mathrm{r} 5 \cdot 8$ \\
\hline I:I & - & Under reflux & $\begin{array}{l}1 \\
3 \\
6\end{array}$ & $\begin{array}{l}19.2 \\
19.9 \\
20.3\end{array}$ & $\overline{I 7 \cdot 4}$ \\
\hline $2: 1$ & $\longrightarrow$ & Under reflux & $\begin{array}{l}0.5 \\
I\end{array}$ & $\begin{array}{l}17 \cdot 1 \\
18 \cdot 7\end{array}$ & $\begin{array}{l}I 6 \cdot 8 \\
I 7 \cdot 4\end{array}$ \\
\hline
\end{tabular}

Table 2. Properties of samples of herring meal no. 3 stored with and without an anti-oxidant, * including those used in the tests of tainting and nutritive value

\begin{tabular}{|c|c|c|c|c|c|c|c|}
\hline \multirow[b]{2}{*}{$\begin{array}{l}\text { Days at } \\
20^{\circ} \text { in air }\end{array}$} & & \multicolumn{3}{|c|}{ Chloroform-methanol extract $\ddagger$} & \multirow[b]{2}{*}{$\begin{array}{l}\text { Ether } \\
\text { extract } \\
(\%)\end{array}$} & \multirow[b]{2}{*}{$\begin{array}{l}\text { Light- } \\
\text { petroleum } \\
\text { extract } \\
(\%)\end{array}$} & \multirow[b]{2}{*}{$\begin{array}{c}\text { Available' } \\
\text { lysine } \\
(\mathrm{g} / \mathrm{I} 6 \mathrm{~g} \mathrm{~N})\end{array}$} \\
\hline & $\begin{array}{c}\text { Colour of } \\
\text { meal } \uparrow\end{array}$ & $\begin{array}{l}\text { Yield } \\
(\%)\end{array}$ & $\begin{array}{l}\text { Iodine } \\
\text { value }\end{array}$ & $\begin{array}{c}\text { Colour } \\
\left(E_{1}^{1} \mathrm{~cm}\right. \\
\text { at } 400 \mathrm{~m} \mu)\end{array}$ & & & \\
\hline ० & $4 \cdot 7$ & $17 \cdot 4$ & $13^{6}$ & 0.8 & $12 \cdot 6$ & $12 \cdot 1$ & $7 \cdot 01$ \\
\hline 30 & $5 \cdot 4(-)$ & $17.8(\rightarrow)$ & $94(-)$ & $2 \cdot 1(-)$ & 一 & - & - \\
\hline 36 & $-(5 \cdot 0)$ & $-(17 \cdot 6)$ & $-(128)$ & $-(0.9)$ & - & 一 & - \\
\hline 54 & $6 \cdot 5(-)$ & $17 \cdot 4(-)$ & $92(-)$ & $2 \cdot 6(-)$ & $\longrightarrow$ & - & - \\
\hline 100 & $6 \cdot 6(5 \cdot 1)$ & $17.7(17.5)$ & $92(125)$ & $3.0(1 \cdot 0)$ & - & - & - \\
\hline 120 & $6 \cdot 5(5 \cdot 2)$ & $17 \cdot 6(17.5)$ & $90(124)$ & $3 \cdot I(I \cdot I)$ & $12 \cdot 2(12 \cdot 5)$ & $11 \cdot 5(11 \cdot 9)$ & - \\
\hline 201 & $7 \cdot 3(5 \cdot 5)$ & $16 \cdot 9(17 \cdot 4)$ & $90($ II 7$)$ & $3 \cdot 2(I \cdot 3)$ & - & - & $6.60(6.89)$ \\
\hline 286 & $7 \cdot 5(5 \cdot 9)$ & $17 \cdot 3(17 \cdot 5)$ & $89(\mathrm{I} I 6)$ & $3 \cdot 4(I \cdot 3)$ & - & - & $6.59(6.71)$ \\
\hline 365 & $8 \cdot 0(6 \cdot 9)$ & $17 \cdot I(17 \cdot 4)$ & 88 (I I 5) & $3 \cdot 5(I \cdot 2)$ & I I. $8(12 \cdot 1)$ & $10.9(1 I \cdot 7)$ & $6.43(6.69)$ \\
\hline
\end{tabular}

* The figures in parentheses refer to meals containing $0.025 \%$ 2,6-di-t-butyl-4-methylphenol + $0.01 \%$ citric acid.

+ Lovibond $R+Y$ units.

$\ddagger$ Purified by re-solution in chloroform. 
given in Table 2. The effect of anti-oxidants on the rate of oxidation is described more fully on p. 100 .

Effects of heat on herring meals. As expected from the previous work (Lea et al. I958), storage for 98 days in air at $10^{\circ}$ and $6.1 \%$ moisture caused extensive oxidation of the oil, the iodine value falling from ${ }^{3} 36$ to 74 and the colour increasing from 0.8 to $3 \cdot$ I units, but the loss of available lysine was again very small $(<4 \%)$.

When the oxidized meal was heated for $30 \mathrm{~h}$ at $45^{\circ}$ in the absence of oxygen there was no change in its available lysine content, but at 65,85 and $100^{\circ}$ progressively greater losses occurred. The fresh meal, on the other hand, showed no change in lysine content at any of these temperatures. At $I 15^{\circ}$, and particularly at $130^{\circ}$, severe losses of available lysine occurred in both meals, the unoxidized suffering nearly as badly at the highest temperature as the oxidized (Fig. I $A$ ).

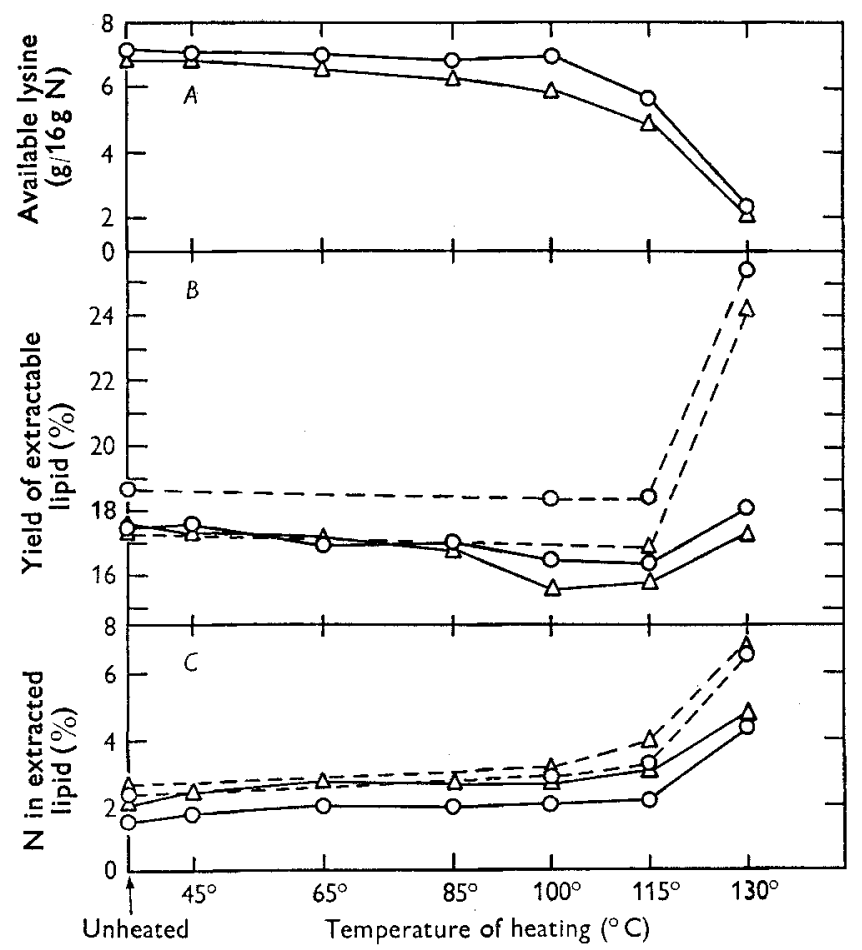

Fig. I. Effect of heating fresh or oxidized herring meal for $30 \mathrm{~h}$ in the absence of oxygen on $(A)$ available lysine content, $(B)$ extractable lipid and $(C)$ nitrogen content of extractable lipid. $O$, fresh meal; $\triangle$, oxidized meal. In $B$ and $C:---$, crude chloroform-methanol extract; - - chloroform-soluble fractions of these extracts.

Both meals darkened on heating (Table 3). The fresh meal heated to 100 or $115^{\circ}$ in nitrogen retained its original greyish-brown shade with only a very slight darkening, but at $130^{\circ}$ it became appreciably darker and browner. The oxidized meal was initially darker and showed a much greater degree of darkening on heating and a much redder shade of brown. The reproducibility of the Lovibond readings on the darker meals was poor. 
The percentage of lipid extractable from the meal tended to drift downwards with increasing temperature of heating, especially with the oxidized meal, until at the highest temperature used $\left(130^{\circ}\right)$ there was a sudden marked increase (Fig. I $B$ ). This increase was much greater when measured in terms of the crude chloroform-methanol extract than when the 'purified lipid' (chloroform-soluble fraction) was used (Fig. I $B$ ).

The nitrogen content of the lipid extracts increased but little with temperatures up to $100^{\circ}$, but thereafter it increased appreciably for meal heated at $I 15^{\circ}$ and sharply for meal heated at $130^{\circ}$. Again, the changes were greater in the crude than in the purified lipid extracts (Fig. IC).

Table 3. Effect of heating on some properties of herring meal no. 3

\begin{tabular}{|c|c|c|c|c|}
\hline \multirow[b]{2}{*}{ Meal } & \multirow[b]{2}{*}{ Heat treatment } & \multirow{2}{*}{$\begin{array}{l}\text { Colour of } \\
\text { meal }^{*}\end{array}$} & \multicolumn{2}{|c|}{ Purified lipid extract } \\
\hline & & & Colour $\uparrow$ & Iodine value \\
\hline Fresh & $\begin{array}{l}\text { None } \\
\text { 3o h without air at: } \begin{aligned} & 45^{\circ} \\
& 65^{\circ} 85^{\circ} \\
& 100^{\circ} \\
& 115^{\circ} \\
& 130^{\circ}\end{aligned}\end{array}$ & $\begin{array}{l}4 \cdot 7 \\
4 \cdot 8 \\
5 \cdot 0 \\
5 \cdot 2 \\
5 \cdot 3 \\
5 \cdot 7 \\
7 \cdot 4\end{array}$ & $\begin{array}{l}0.8 \\
1 \cdot 0 \\
0 \cdot 9 \\
1 \cdot 0 \\
1 \cdot 0 \\
1 \cdot 0 \\
1 \cdot 3\end{array}$ & $\begin{array}{l}132 \\
126 \\
125 \\
127 \\
128 \\
127 \\
110\end{array}$ \\
\hline Oxidized & 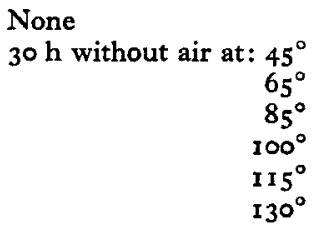 & $\begin{array}{r}6 \cdot 6 \\
6 \cdot 8 \\
8 \cdot 4 \\
11 \cdot 0 \\
13 \cdot 0 \\
13 \cdot 5 \\
14 \cdot 0\end{array}$ & $\begin{array}{l}3 \cdot 7 \\
4 \cdot 8 \\
5 \cdot 1 \\
5 \cdot 2 \\
5 \cdot 5 \\
5 \cdot 5 \\
4 \cdot 4\end{array}$ & $\begin{array}{l}74 \\
73 \\
76 \\
77 \\
69 \\
76 \\
78\end{array}$ \\
\hline Fresh & $\begin{array}{l}\text { None } \\
3 \circ \mathrm{h} \text { in air at: } 45^{\circ} \ddagger \\
65^{\circ} \ddagger \\
85^{\circ} \ddagger\end{array}$ & $\begin{array}{l}4.7 \\
5.0 \\
6.0 \\
8.5\end{array}$ & $\begin{array}{l}0 \cdot 8 \\
1 \cdot 9 \\
2 \cdot 1 \\
2 \cdot 6\end{array}$ & $\begin{array}{l}132 \\
123 \\
118 \\
109\end{array}$ \\
\hline
\end{tabular}

Table 4. 'Bound' lipid in fresh and oxidized herring meal no. I

\begin{tabular}{|c|c|c|c|c|}
\hline \multirow[b]{2}{*}{ Storage } & \multirow{2}{*}{$\begin{array}{l}\text { Period of } \\
\text { extraction } \\
\text { with boiling } \\
\text { chloroform- } \\
\text { methanol } \\
\text { (h) }\end{array}$} & \multicolumn{2}{|c|}{$\begin{array}{l}\text { Conditions of hydrolysis } \\
\text { of the solvent-extracted } \\
\text { meal with boiling } \mathrm{HCl}\end{array}$} & \multirow{2}{*}{$\begin{array}{l}\text { Lipid recovered } \\
\text { by ether- } \\
\text { extraction of } \\
\text { hydrolysate } \\
\text { (as percentage of } \\
\text { original meal) }\end{array}$} \\
\hline & & $\begin{array}{c}\text { Time } \\
\text { (h) }\end{array}$ & $\begin{array}{l}\text { Normality } \\
(\mathrm{N})\end{array}$ & \\
\hline $\begin{array}{l}\text { None } \\
\text { None }\end{array}$ & 3 & $\begin{array}{c}0.5 \\
24\end{array}$ & $\begin{array}{l}3 \\
6\end{array}$ & $\begin{array}{l}0.13 \\
0.19\end{array}$ \\
\hline $\begin{array}{l}\text { None } \\
\text { None }\end{array}$ & $\begin{array}{r}3 \\
120\end{array}$ & $\begin{array}{l}24 \\
0.5\end{array}$ & $\begin{array}{l}6 \\
3\end{array}$ & $\begin{array}{l}0.19 \\
0.05\end{array}$ \\
\hline In nitrogen 12 months at $25^{\circ *}$ & 120 & 0.5 & $\begin{array}{l}3 \\
3\end{array}$ & 0.06 \\
\hline In air 12 months at $25^{\circ} \mathrm{H}$ & 3 & 0.5 & 3 & $0.5 \mathrm{I}$ \\
\hline In air 12 months at $25^{\circ} \dagger$ & 3 & 24 & 6 & 0.55 \\
\hline In air 12 months at $25^{\circ} \dagger$ & 120 & 0.5 & 3 & 0.59 \\
\hline
\end{tabular}


Changes in fresh meal heated in the presence of air, so that oxidation and heating could occur simultaneously, are summarized in the lower part of Table 3 .

Binding of oxidized fat by fish protein. The results in Table 4 show that, after prolonged extraction of fresh or nitrogen-stored herring meal with boiling chloroformmethanol, very little 'bound' lipid remained to be liberated by subsequent acid hydrolysis. From oxidized meal a small but definitely larger amount of 'bound' lipid was recovered.

Table 5. Thiobarbituric acid (TBA) reaction of extracted herring meal no. 2

$\begin{array}{lcc} & \begin{array}{c}\text { Period of extraction } \\ \text { with boiling } \\ \text { chloroform-methanol }\end{array} & \begin{array}{c}\text { Intensity of colour } \\ E_{1 \%}^{1 \%} \text { at } 540 \mathrm{~m} \mu\end{array} \\ \text { Fresh } & (\mathrm{h}) & 0.23 \\ & 24 & 0.15 \\ \text { Stored } 12 \text { months in air } & 96 & 0.14 \\ \text { at } 25^{\circ *} & 192 & 0.95 \\ & 24 & 0.66 \\ * 8 \% \text { loss of 'available' lysine as compared with fresh meal. }\end{array}$

$T B A$ test. As has recently been reported (Yu \& Sinnhuber, 1957), most of the TBA-reacting material remains in fish meal, presumably in association with the protein, when the oil is extracted by solvents. The fraction so remaining was, however, found to decrease slowly during continued extracton for periods that were extremely long compared with those normally adequate for virtually complete extraction of the oil (Tables $x$ and 5 ). The reaction of oxidized meal after each period of extraction was several times stronger than that of fresh meal.

Reaction of fish muscle with propanal. Propanal reacted rapidly with 'dry' cod muscle; less than $20 \%$ of the added aldehyde could be recovered by extraction with ethanol after 1, 2 and $20 \mathrm{~h}$ at 60,37 and $15^{\circ}$, respectively (Fig. 2).

The free amino groups of the fish muscle apparently continued to react after most of the extractable aldehyde had disappeared. Two reasons for this behaviour are likely. One is the reaction of a second amino group with the combined aldehyde molecule, as is known to occur, with methylene-bridge formation, in reacting with formaldehyde. The second is the possibility, not unreasonable from knowledge of sugar-amine browning reactions, that in the early but not in the later stages of the reaction the amine-aldehyde complex may hydrolyse in the acid Van Slyke reagent with partial regeneration of the amino compound (but not of the aldehyde).

The reaction gradually came to a stop when losses of $12,3 \mathrm{I}$ and $33 \%$ of the original free amino groups at 15,37 , and $60^{\circ}$, respectively, had occurred (Fig. 2 ). These values were still unchanged after 16 days.

The properties of the larger-scale cod-propanal preparation $\left(48 \mathrm{~h}\right.$ at $\left.37^{\circ}\right)$ used in the feeding tests are given in Table 6, together with those of a control sample heated under the same conditions without the propanal. The small fall in amino nitrogen observed in the latter sample was only of the order of the error in the determination 
and indicates that no appreciable 'browning' reaction occurred in the fish muscle itself under the conditions of the experiment. The 'available' lysine figures show that the $\epsilon$-amino groups of the available lysine residues accounted for about two-thirds of the total free amino groups of the control cod muscle, as measured by the Van Slyke method, the remainder presumably being contributed largely by the free $\alpha$-amino groups of peptides, amino acids and proteins. Reaction with the amount of propanal added destroyed approximately the same proportion $(35 \%)$ of the lysine $\epsilon$-amino groups as of the total free amino groups.

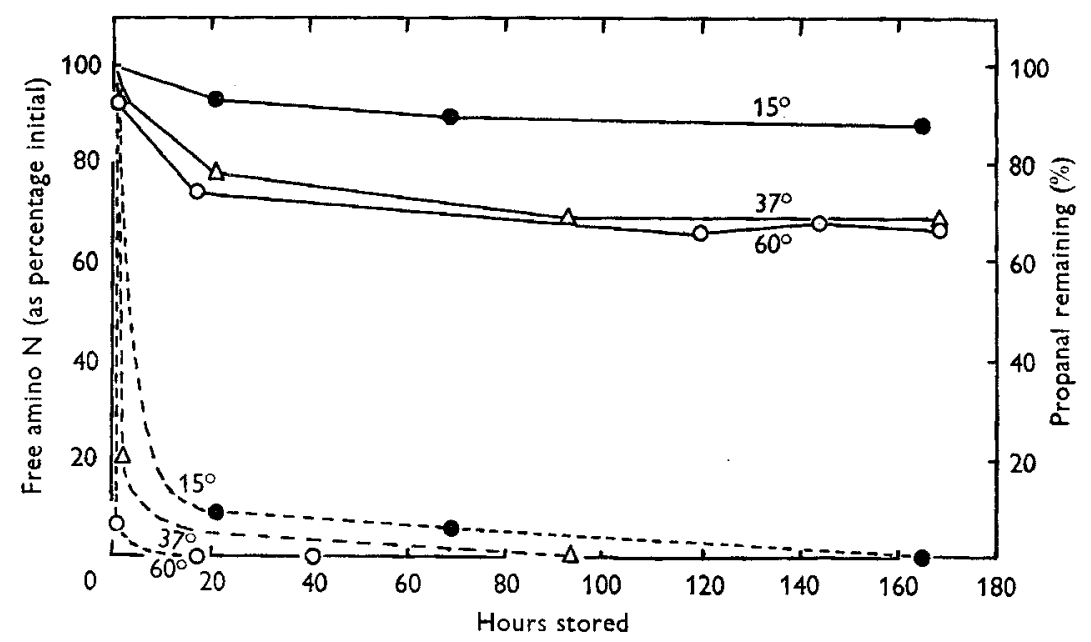

Fig. 2. Reaction of the free amino groups of vacuum-dried cod muscle (initial free amino $N$ content, $84^{*} \mathrm{mg} / \mathrm{g}$ total $\mathrm{N}$ ) with propanal (initial content approximately 2 equiv./free amino group) during storage at three temperatures. - - free amino $\mathrm{N}$; --- , propanal.

Table 6. Reaction of cod muscle (E) with propanal* during 48 h at $37^{\circ}$

\begin{tabular}{|c|c|c|c|c|}
\hline \multirow[b]{2}{*}{ Sample } & \multirow[b]{2}{*}{$\begin{array}{l}\text { Total N } \\
\text { (mg/g) }\end{array}$} & \multicolumn{2}{|c|}{ Amino $\mathrm{N}$} & \multirow{2}{*}{$\begin{array}{c}\text { 'Available' } \\
\text { lysine } \\
\text { (g/16 g N) }\end{array}$} \\
\hline & & $\mathrm{mg} / \mathrm{g}$ & $\underbrace{}_{\text {total } \mathrm{mg}}$ & \\
\hline $\begin{array}{l}\text { h propanal }(\mathrm{F}) \\
\text { ated without propanal }\end{array}$ & $\begin{array}{l}130.2 \\
130.9\end{array}$ & $\begin{array}{l}7.04 \\
10.8\end{array}$ & $\begin{array}{l}54 \cdot x \\
82 \cdot 6\end{array}$ & $\begin{array}{l}5 \cdot 72 \\
8 \cdot 87 \dagger\end{array}$ \\
\hline
\end{tabular}

* Initial content approximately 2 equiv./free amino group.

$\uparrow$ Corresponds to $53 \cdot 2 \mathrm{mg}$ free $\epsilon$-amino $\mathrm{N} / \mathrm{g}$ total $\mathrm{N}$.

Properties of 'burnt' herring meals. Two of the 'burnt' meals were much more seriously affected than the third: they were dark in colour and gave very low values for available lysine (Table 7). Values for the nutritive value of one of these badly 'burnt' commercial meals are included with those of the other experimental materials tested (see Table 9).

Anti-oxidant experiments. Table 8 completes presentation of the results of an experiment of which the earlier stages were reported by Lea et al. (1958). After 13 months at $25^{\circ}$ the oil in the meal containing $0.005 \% \mathrm{BHT}$ had oxidized to a considerable 
extent, but still showed rather less change than the oil in the untreated meal at 2 months.

In a second series of experiments (Fig. 3 ) the $\mathrm{pH}(6 \cdot 2)$ of the herring meal used (no. 3) was not affected by citric acid at the maximum concentration ( $0.1 \%$ ) added. The protection afforded by $0.005 \%$ BHT was less with this meal (made from formaldehyde-preserved herring) than in the previous experiment but 0.025 or $0.05 \%$ gave better results.

Table 7. Some properties of commercial 'burnt' herring meals and of a meal of normal quality

\begin{tabular}{|c|c|c|c|c|c|c|c|c|}
\hline \multirow[b]{3}{*}{ Sample } & \multirow[b]{3}{*}{$\begin{array}{c}\text { Moisture } \\
(\%)\end{array}$} & \multirow[b]{3}{*}{$\begin{array}{c}\text { 'Available' } \\
\text { lysine } \\
(\mathrm{g} / \mathrm{I} 6 \mathrm{~g} N)\end{array}$} & \multicolumn{5}{|c|}{ Extractable lipid } & \multirow[b]{3}{*}{$\begin{array}{c}\text { 'Bound' } \\
\text { lipid* } \\
(\%)\end{array}$} \\
\hline & & & \multicolumn{2}{|c|}{ Crude } & \multicolumn{3}{|c|}{ Purified } & \\
\hline & & & $\begin{array}{l}\text { Yield } \\
(\%)\end{array}$ & $\begin{array}{c}N \\
(\%)\end{array}$ & $\begin{array}{l}\text { Yield } \\
(\%)\end{array}$ & $\begin{array}{c}N \\
(\%)\end{array}$ & $\begin{array}{c}\text { Iodine } \\
\text { value }\end{array}$ & \\
\hline Normal & $6 \cdot 1$ & $7 \cdot 8$ & - & - & $14 \cdot 6$ & $2 \cdot 0$ & ror & 0.04 \\
\hline $\begin{array}{l}\text { G, slightly } \\
\text { burnt }\end{array}$ & $9 \cdot 5$ & $5 \cdot 8$ & 15.7 & $4 \cdot 4$ & I2:9 & $2 \cdot 5$ & 104 & - \\
\hline D, burnt & $7 \cdot$ & $3 \cdot 2$ & $x 6 \cdot 2$ & $4.7 t$ & $12 \cdot 3$ & $2 \cdot 4$ & 60 & 0.05 \\
\hline H, burnt & $8 \cdot 0$ & 3.5 & $\mathrm{I} 1 \cdot 3$ & 5.4 & $9 \cdot 7$ & $3 \cdot 4$ & 63 & - \\
\hline
\end{tabular}

* Obtained from the fully extracted ( $120 \mathrm{~h}$ reflux with $2: 1$ chloroform-menthanol) meal by acid hydrolysis and re-extraction with ether.

$\dagger$ Chloroform-insoluble material obtained from this crude extract contained $10.6 \% \mathrm{~N}$.

Table 8. Effect of anti-oxidants on the iodine value and colour of the oil extracted* from herring meal no. 2 (Lea et al. 1958) stored in air at $25^{\circ}$

\begin{tabular}{|c|c|c|c|c|c|}
\hline \multirow[b]{2}{*}{ Anti-oxidant $\dagger$} & \multicolumn{5}{|c|}{ Storage (months) } \\
\hline & $\circ$ & 2 & 4 & 9 & 13 \\
\hline \multicolumn{6}{|c|}{ Iodine value } \\
\hline- & I36 & 98 & 90 & 一 & - \\
\hline $\mathrm{DBHQ}+\mathrm{CA}$ & 136 & 128 & $1 \times 8$ & 108 & I06 \\
\hline $\mathrm{BHT}+\mathrm{CA}$ & 136 & 131 & 125 & $1 \times 5$ & II 2 \\
\hline \multicolumn{6}{|c|}{$E_{1 \mathrm{em}}^{1 \%}$ at $400 \mathrm{~m} \mu$} \\
\hline- & 0.5 & $2 \cdot 4$ & $3 \cdot 2$ & - & - \\
\hline $\mathrm{DBHQ}+\mathrm{CA}$ & 0.5 & 0.9 & $\mathrm{I} \cdot 3$ & $2 \cdot 5$ & $3 \cdot I$ \\
\hline $\mathrm{BHT}+\mathrm{CA}$ & 0.5 & 0.8 & $I \cdot O$ & $\mathrm{x} \cdot 8$ & $2 \cdot 2$ \\
\hline
\end{tabular}

* Cold extraction with chloroform-methanol.

t $0.005 \%$ of each substance: DBHQ, 2,5-di-t-butylhydroquinone; CA, citric acid; BHT, 2,6-di-tbutyl-4-methylphenol.

A third series of experiments with the same meal (no. 3 ) which had been stored under nitrogen at $-20^{\circ}$ is still incomplete but present indications are that, at the concentration used $(0.025 \%$ without citric acid), the aromatic amine anti-oxidants DPPD and EMQ are both more effective than the phenolic inhibitors BHT and MBHQ (monobutylhydroquinone) (Fig. 4).

Stabilizing effect of heat. The initial rates of oxidation of herring meal preheated for $2 \mathrm{~h}$ in the absence of oxygen at 90,100 or $110^{\circ}$ were found to be progressively 
lower than that of the unheated meal, and meal that had previously been stored for I 2 months in nitrogen at $20^{\circ}$ also showed a slightly reduced rate of oxidation compared with the fresh meal. Preheating at the same temperatures $\left(90-110^{\circ}\right)$ in the presence of a limited amount of oxygen rather surprisingly increased the stabilizing effect (Fig. 5), but after storage for a month in oxygen at $20^{\circ}$ the levels of oxygen absorption even of these meals were beginning to approach that of the control.

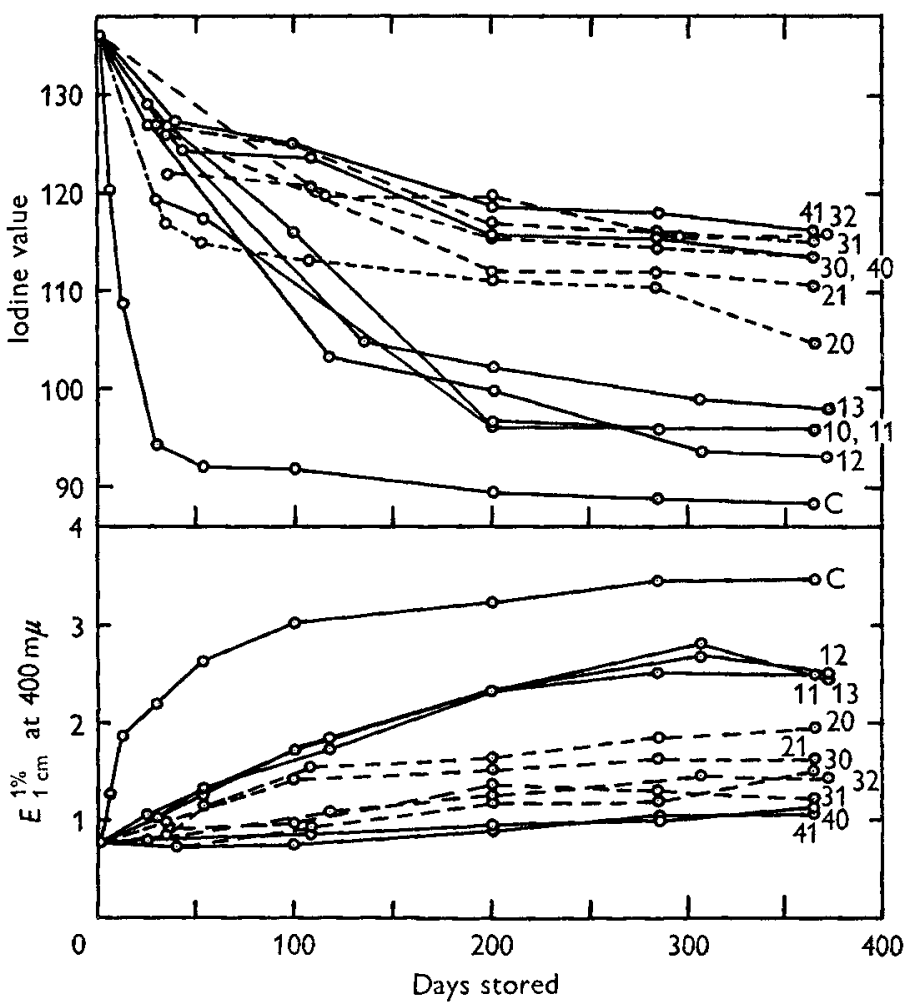

Fig. 3. Effect of 2,6-di-t-butyl-4-methylphenol (BHT), with or without citric acid (CA), on the iodine value and colour of oil extracted from herring meal no. 3 , stored in air at $20^{\circ}$. C, control; ro, 0.005\% BHT; r I, 0.005\% BHT +0.01 \% CA; r2, 0.005\% BHT +0.05\% CA; 13, 0.005\% BHT +0.1 \% CA; 20, 0.01\% BHT; 21, 0.01 \% BHT +0.01 \% CA; $30,0.025 \%$ BHT; 3 I, 0.025\% BHT +0.01\% CA; 32, 0.025\% BHT +0.I \% CA; 40, 0.05\% BHT; 4I, $0.05 \% \mathrm{BHT}+0.01 \% \mathrm{CA}$.

\section{Nutritive value of the meals}

'Available' lysine. The small drop in available lysine $(8 \%)$ which occurred during the storage of meal no. 3 for 12 months in air at $20^{\circ}$ (Table 2) was almost exactly the same as that previously observed $(9 \%)$ for meals nos. I and 2 stored for the same period at $25^{\circ}$ (Lea et al. 1958$)$. Meal no. 3 containing anti-oxidant $(0.025 \% \mathrm{BHT}+$ $0 \circ 01 \%$ citric acid) suffered about half this loss (Table 2 ).

The much larger losses of available lysine (up to $70 \%$ ) which occurred when oxidized (or, at sufficiently high temperatures, unoxidized) meals were heated are shown in 
Fig. $I$ and Table 7 , and the effect of reaction with propanal on the 'available' lysine of cod muscle is shown in Table 6.

Chick assay for lysine. The results of the lysine assay are set out in Table 9. The chicks were divided into forty-eight groups of four chicks each. Of these 192 chicks, one was killed after an accident and four more died from unknown causes during the trial; the deaths were distributed between diets I, 3 and 9; otherwise the birds

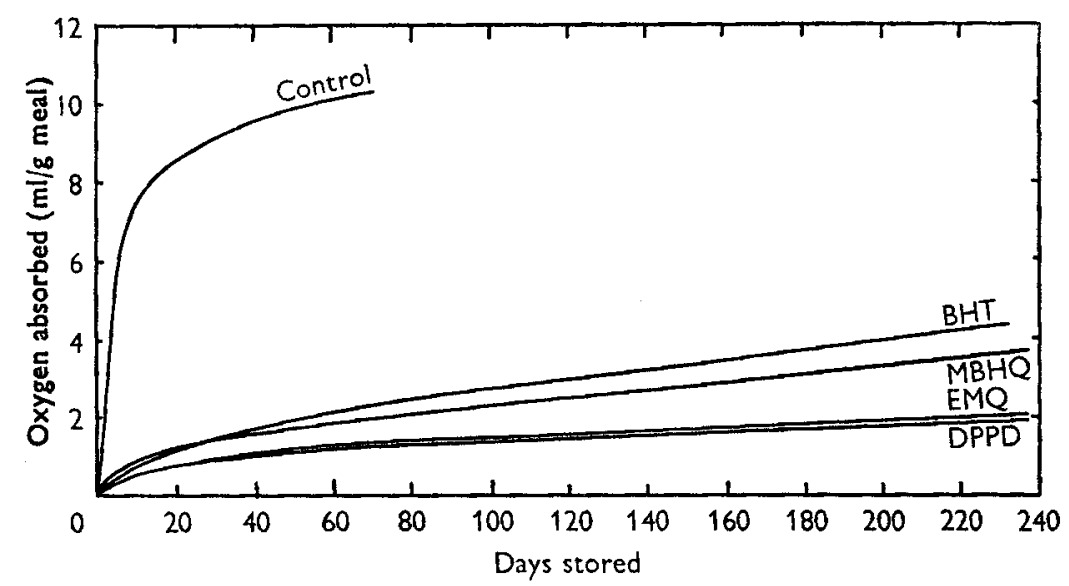

Fig. 4. Effect of anti-oxidants $(0.025 \%)$ on the absorption of oxygen by herring meal no. 3 stored in oxygen at $20^{\circ}$. BHT, 2,6-di-t-butyl-4-methylphenol; MBHQ, monobutylhydroquinone; EMQ, 6-ethoxy-2,2,4-trimethyl-1,2-dihydroquinoline; DPPD, diphenyl-p-phenylenediamine.

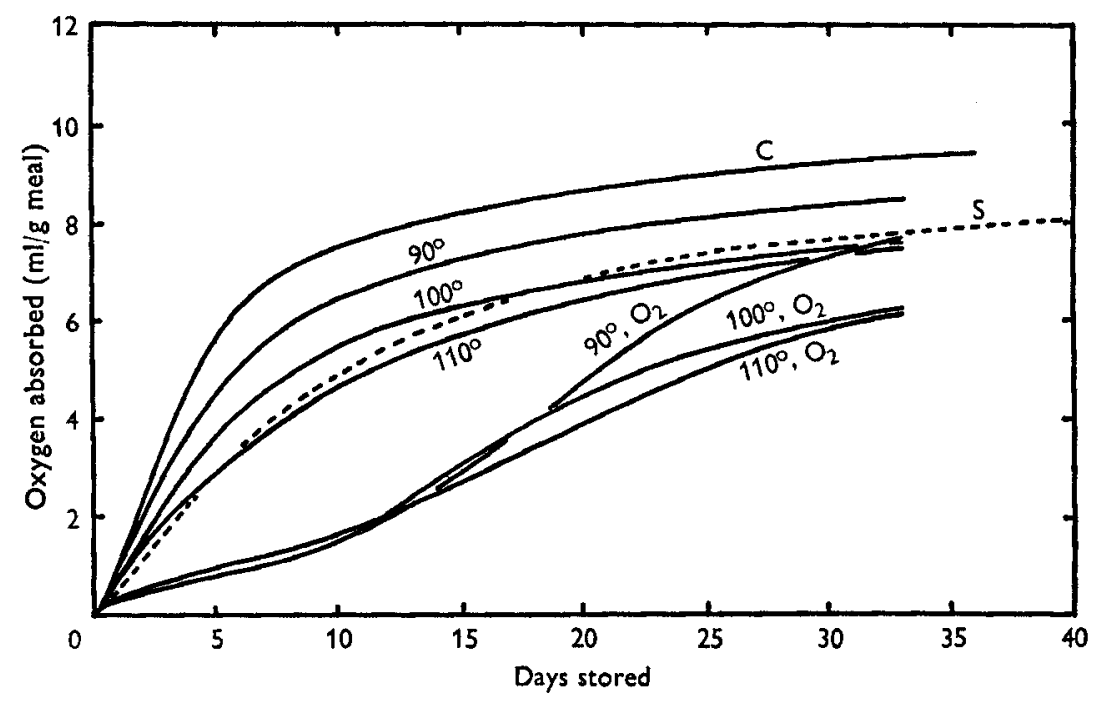

Fig. 5. Effect of preheating, or of storage in nitrogen, on the subsequent absorption of oxygen by herring meal no. 3 when stored in oxygen at $20^{\circ}$. C, fresh meal (control); $\mathrm{S}$, meal stored 12 months at $20^{\circ}$ in nitrogen. Other meals heated for $2 \mathrm{~h}$ at 90,100 or $110^{\circ}$ as indicated, either in the absence of oxygen or in the presence of a limited supply of oxygen (indicated by $\mathrm{O}_{2}$ ). 
maintained a healthy appearance on all the experimental diets and showed no decline in appetite. The weight gains of the chicks were analysed statistically and the betweencage standard errors for the mean gains are shown in Table 9.

The birds on the unsupplemented diet (I) showed the slowest growth and poorest efficiency of food conversion. Fastest growth was obtained with diet 3 , calculated to have the highest lysine content.

Table 9. Calculated contents of crude protein and lysine of the diets and mean weight gain and efficiency of food conversion of the chicks

\begin{tabular}{|c|c|c|c|c|c|c|c|c|}
\hline \multicolumn{4}{|c|}{ Diets } & \multicolumn{5}{|c|}{ Chicks } \\
\hline & & \multicolumn{2}{|c|}{ Composition of diet } & & Weight gain & /chick & Food cc & version \\
\hline No. & $\begin{array}{l}\text { Supplement (to control diet } \\
\text { at expense of starch) }\end{array}$ & $\begin{array}{l}\text { Crude } \\
\text { protein } \\
(\%)\end{array}$ & $\begin{array}{l}\text { Lysine } \\
\text { from sup- } \\
\text { plement } \dagger \\
(\%)\end{array}$ & $\begin{array}{l}\text { No. of } \\
\text { groups } f\end{array}$ & $\begin{array}{l}\text { Absolute (g) } \\
\quad( \pm \text { S.E. })\end{array}$ & $\begin{array}{l}\text { Excess } \\
\text { over } \\
\text { control }\end{array}$ & $\begin{array}{l}\mathrm{g} \text { gain/ } \\
\mathrm{g} \text { food }\end{array}$ & $\begin{array}{l}\text { Excess } \\
\text { over } \\
\text { control }\end{array}$ \\
\hline$\stackrel{\text { I }}{\text { (control) }}$ & None & $24 \cdot 0$ & - & 3 & $49 \cdot 6 \pm 4 \cdot 2$ & - & 0.307 & 一 \\
\hline 2 & $\begin{array}{l}9 \% \text { basal mix }+0.20 \% \\
\text { L-lysine monohydrochloride }\end{array}$ & $e^{27 \cdot 1}$ & +0.23 & 4 & $89 \cdot 9 \pm 3 \cdot 6$ & +40 & 0.475 & +0.17 \\
\hline 3 & $\begin{array}{l}9 \% \text { basal mix }+0 \cdot 40 \% \\
\text { L-lysine monohydrochloride }\end{array}$ & $e^{27 \cdot 3}$ & +0.39 & 4 & $116.7 \pm 3.6$ & +67 & 0.550 & +0.24 \\
\hline 4 & $\begin{array}{l}3.1 \% \text { meal A }\left(\mathrm{N}_{2},-20^{\circ}\right. \\
\text { equivalent to fresh)* }\end{array}$ & $26 \cdot 0$ & +0.15 & 8 & $84 \cdot 7 \pm 2 \cdot 5$ & +35 & 0.464 & +0.16 \\
\hline 5 & $3.1 \%$ meal B (air, $\left.20^{\circ}\right) *$ & $26 \cdot 0$ & +0.14 & 8 & $85 \cdot 4 \pm 2 \cdot 5$ & +36 & $0.45^{8}$ & +0.15 \\
\hline 6 & $\begin{array}{l}\text { 3.1 \% meal C (air, } 20^{\circ} \\
\text { BHT)* }\end{array}$ & $26 \cdot 0$ & +0.14 & 8 & $83 \cdot 8 \pm 2 \cdot 5$ & +34 & 0.452 & +0.15 \\
\hline 7 & $3 \cdot 1 \%$ meal D ('burnt') & $26 \cdot 0$ & +0.06 & 3 & $54 \cdot 5 \pm 4 \cdot 2$ & +15 & 0.330 & +0.02 \\
\hline 8 & $2.0 \% \operatorname{cod} \mathrm{E}$ & $25 \cdot 7$ & +0.15 & 4 & $77 \cdot 7 \pm 3 \cdot 6$ & +28 & 0.442 & +0.14 \\
\hline 9 & $2.0 \%$ 'cod+propanal' F & $25 \cdot 7$ & +0.09 & 4 & $66 \cdot 0 \pm 3 \cdot 6$ & +16 & 0.397 & +0.09 \\
\hline ro & $\begin{array}{l}2.0 \% \mathrm{~F}+0.18 \% \text { L-lysine } \\
\text { monohydrochloride }\end{array}$ & $25 \cdot 8$ & +0.24 & 2 & $92 \cdot 8 \pm 5 \cdot I$ & +43 & 0.476 & +0.17 \\
\hline
\end{tabular}

* Stored 12 months.

t Represents the calculated level of lysine in the diet contributed by the supplements-made up from the chemically 'available' lysine in the proteins plus the added lysine. The basal diet alone was calculated to contain $0.53 \%$ 'available' lysine.

$\ddagger$ Four chicks/group.

Of the four herring-meal diets, 4,5 and 6 gave responses that did not differ significantly from each other. The performance of chicks receiving meal D (diet 7 ) that had been stored in bulk commercially and overheated (Table 7) was very much poorer.

Amongst the chicks receiving the vacuum-dried cod fillets, diet 9 , in which material treated with propanal (Table 6) was used, supported considerably poorer growth than diet 8 containing untreated fillets, but it supported better growth when supplemented with lysine (diet ro).

The overall relation between the calculated lysine content of the various diets and the efficiency of food conversion obtained with them is shown in Fig. 6. It can be seen 
that in general there was a close correlation, but with a slightly greater response to all three laboratory-stored herring meals than would have been predicted from their chemical analysis.

\section{Palatability tests}

Eggs. The experimental diets (Table ro), which were given for 2 months, were not designed to compare the efficacy of the meals as protein supplements for egg production, but the records showed no gross difference in egg production between the four groups.

Testing the egg yolks for flavour was found to be difficult owing to variations from one egg to another, apparently independent of the feed. Since no 'fishy' flavour could be distinguished with any consistency by any member of the panel, the results

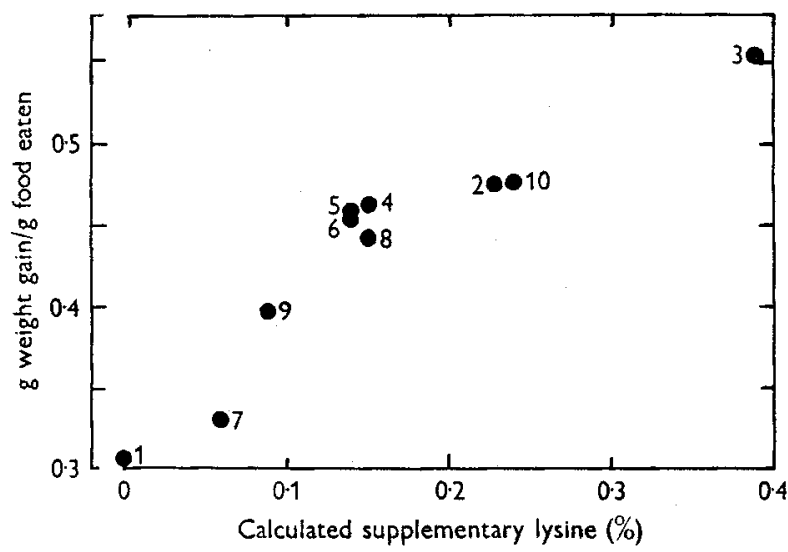

Fig. 6. Chemical values for the 'available' lysine and added crystalline lysine present as supplements in the diets used and mean weight gain/g food eaten of the chicks receiving these diets. The coding, $\mathrm{I}-\mathrm{ro}$, of the individual diets is explained in Table 9.

Table 10. Effect of stored herring meal in the hen's diet on the flavour of the egg yolk

$\begin{array}{cc}\begin{array}{c}\text { No. of } \\ \text { tests }\end{array} & \begin{array}{c}\text { Days on } \\ \text { diet }\end{array} \\ \text { I I } & 2-62\end{array}$

$\begin{array}{cccc}\text { Flavour score* (range and mean) with diet } \\ \text { G } & \text { A } & \text { B } & \text { C } \\ 0-0.7 & 0-0.8 & 0-0.5 & 0-0.7 \\ 0.2 & 0.2 & 0.2 & 0.2\end{array}$

* 0 , no 'off' flavour; $I$, very slight 'off' flavour; 2 , definite 'off' flavour; 3 , strong 'off' flavour.

$+G$, control (groundnut meal) diet without herring meal; $A, 8 \%$ herring meal stored 4 months in $\mathrm{N}_{2}$ at $-20^{\circ}$ (equivalent to fresh meal); $\mathrm{B}, 8 \%$ herring meal stored 4 months in air at $20^{\circ} ; \mathrm{C}, 8 \%$ herring meal (0.025\% 2,6-di-t-butyl-4-methylphenol) stored 4 months in air at $20^{\circ}$.

have been presented only in summary form in Table 10. One of the four panel members believed he could detect a slight 'fishy' taint in the isolated yolk in one of the eleven tests and on two occasions in a lightly boiled egg, from birds on the diet containing unoxidized herring meal (A), but he failed to identify eggs from this source in the great majority of the tests.

Meat. No significant flavour differences, and in particular no 'fishy' off-flavour, 
could be detected in the flesh of birds roasted at the end of I or 2 months on the experimental diets. Roasting is difficult to control precisely and the degree of browning was not always exactly the same. Nevertheless, any marked taint in the birds fed on herring meal should have been detected by the panel, which was quite unable to pick out the control bird that had received no fish meal. A few tests on diced, steamed muscle gave similar results.

\section{DISCUSSION \\ Chemical changes}

Interaction between oxidized fat and protein. As indicated by Lea et al. (1958) the present investigation of the changes occurring in herring meal during storage was undertaken partly because the experiments of 'Tappel (1955) on 'model' systems containing protein and linoleic acid or cod-liver oil had indicated that oxidizing fat could react with protein to produce chemical changes, suspected to be in part at least aldehyde-amine 'browning' reactions, which might result in a fall in the nutritive value of the protein. Stored herring meal seemed to be a very suitable food in which to look for such changes.

Subsequently, however, Venolia \& Tappel (1958), from the results of an investigation of the oxidation of Japanese sardine oil emulsified with aqueous egg albumin, concluded that the oxidized monomer (principally hydroperoxide and carbonylic compounds) formed by a rapid reaction of the oil with oxygen could either condense directly to polymeric material (which could then be adsorbed on to the protein) or could react chemically with protein to give a co-polymer by a carbonyl-amine type of browning reaction. Because the temperature coefficient for the formation of brown polymers in their system was near that for fat oxidation and much lower than is usual for an amino-sugar browning reaction, and because acetylation of the free amino groups of the protein and the addition of sulphur dioxide (an inhibitor of aldehydeamine browning reactions) both increased rather than decreased the rate of browning, they concluded that the carbonyl-amine reaction, i.e. the chemical reaction with the protein, must be so slow as to be relatively unimportant.

Our own finding (Lea et al. 1958) that the loss of available lysine in stored herring meal, although real, is usually small in relation to the degree of fat oxidation and polymerization occurring is not directly in conflict with Venolia \& Tappel's (1958) views. Our present results confirm the small losses of lysine which occur during oxidation of the fat of herring meal at so or $20^{\circ}$ and show that higher temperatures, which can easily develop as a result of the oxidation itself when meal is stored in bulk, favour the binding of lysine, apparently by accelerating its reaction with fat oxidation products (Fig. 1 $A$ ). The non-oxidative reaction which causes a very rapid loss of available lysine at still higher temperatures is considered below (p. 109).

Also very recently Narayan \& Kummerow (1958) have tested Tappel's (1955) original co-polymerization theory and have concluded that the complexes formed between autoxidized linoleic acid and egg albumin do not involve covalent bonding between the oxidized fatty acid and reactive groups of the protein, but are more likely to be due to adsorption based on multiple hydrogen bonding. However, the losses of available lysine and other findings reported in our own work would seem to indicate 
that this view cannot be entirely correct and that damage to the protein by reaction with products of fat oxidation does occur to a limited extent under some conditions.

Chemically, it is difficult to establish the nature of the combination into which the missing lysine $\epsilon$-amino groups have entered. It is tempting to conclude that the losses of fat extractable by ether or light petroleum which occur when fish meal is stored in air are due to combination with the protein. But these losses of extractable lipid are much smaller when chloroform-methanol is the extracting solvent (Table 2) and, in any event, the reaction of unsaturated fat with oxygen will itself cause an increase in weight as oxygen is taken up and a subsequent decrease in weight as the oxidation product decomposes with loss of water, carbon dioxide and other volatile products. These changes, which overlap, are quite large enough in the oil of fish meal to invalidate any conclusions concerning possible interactions of the oxidized fat with protein.

'Bound' lipid in the stored meals. Determination of the lipid remaining attached to the meal after prolonged extraction with boiling chloroform-methanol (which rapidly extracts most of the oxidized as well as the unoxidized fat) demonstrates the presence in the meal, and particularly in the oxidized meal, of small amounts of lipid much more resistant to solvent extraction than the great bulk of the fat (Table 4). The amounts of 'bound' lipid recovered after acid hydrolysis, although considerably smaller, are comparable to the small amounts of lysine which become unavailable on storage of the meal in air. Water-soluble, volatile and acid-labile lipid fragments would not be recovered by the method used.

Against the theory connecting 'bound' lipid with loss of lysine is the failure to recover more than a very small quantity of 'bound' lipid from a 'burnt' commercial meal that had suffered a particularly heavy loss of 'available' lysine ('Table 7). But this meal appears to have reached a very high temperature in the stack, and other lysine-inactivating reactions, independent of oxidation, which are known to occur when fish protein is exposed to high temperatures (Carpenter et al. 1957) may have been very largely responsible. Evidence of such reactions has been obtained in our own heating experiments and is discussed further below.

South African workers (Stander \& Rowan, 1956) have observed losses in total fat and increases in 'oxidized' fat (fat insoluble in ether and fat not extractable by ether without hydrolysis) in pilchard meal heated for $90 \mathrm{~h}$ at 60 or $77^{\circ}$ in the presence of oxygen.

Reaction of volatile aldehydes with fish muscle. Volatile carbonylic compounds, particularly aldehydes which arise as degradation products of the first-formed peroxides, are also produced in relatively small quantities when unsaturated fats oxidize, and propanal is known to be among the volatile products of the oxidation of fish oils. It is difficult, however, to demonstrate the occurrence of a reaction between such substances and protein in a stored fish meal because the aldehydic component of a browning reaction cannot usually be recovered by hydrolysis: Mohammad, Olcott \& Fraenkel-Conrat (1949) were able to recover little or no acetaldehyde after acid hydrolysis of a reaction product of aqueous bovine serum albumin and acetaldehyde. 
It is not surprising therefore that steam distillation of stored fish meal in the presence of acid yielded only traces of substances capable of combining with bisulphite.

However, the experiments summarized in Fig. 2 and Table 6 show that propanal reacts very rapidly with 'dry' fish muscle. At $37^{\circ}$ two equivalents of propanal (based on the total free amino nitrogen) were found to disappear for the loss of only about one-third of the total free amino groups (and the same proportion of the 'available' lysine); at $15^{\circ}$ only about one-eighth of the total free amino groups was destroyed. Obviously, stoichiometric combination with the $\epsilon$-amino groups of lysine is by no means the only reaction occurring. Some of the extra aldehyde probably reacts with the original amine-aldehyde condensation product and some with other reactive groups of the protein, and part may perhaps polymerize or oxidize at the protein surface.

It would appear from these findings that aldehydic decomposition products of oxidizing fat can rapidly destroy available lysine under conditions similar to those existing in fish meal, but that damage to the nutritive value of the protein will be limited by the fact that a large proportion of the aldehyde produced, particularly at low storage temperatures, will probably be destroyed by reactions not directly involving the inactivation of lysine.

The TBA reaction. One aldehydic product of the autoxidation of fats, and particularly of highly unsaturated fats, is the substance, believed to be malonic dialdehyde, which gives the characteristic colour reaction of rancid fats with 2-thiobarbituric acid. As shown in Table 5, the TBA reaction of fish meals remains very largely associated with the insoluble residue even after very prolonged extraction of the meal with boiling chloroform-methanol, and it would seem likely that malonic dialdehyde, and probably other carbonylic fat oxidation products also, are firmly bound to nonfatty material and particularly to the protein. Such binding might well be by chemical reaction with free amino groups, of which a major proportion will be those of the lysine side-chains.

Effect of heat on herring meal. The view that damage to the protein at low and moderate temperatures occurs largely as the result of a reaction with preformed fat oxidation products is further supported by the results of the heating experiments (Fig. $r$ ). Storage of herring meal for 3 months in air at $10^{\circ}$ caused extensive oxidation of the fat, but reduced the available lysine by less than $4 \%$. Obviously the lysine-inactivating reaction is comparatively slow at normal storage temperatures: even after 12 months at $20^{\circ}$ the available lysine had fallen by only $8 \%$ (Table 2 ). Subsequent heating of the ( 3 months) oxidized meal in nitrogen at $100^{\circ}$ for $30 \mathrm{~h}$ reduced the available lysine by a further $12 \%$, whereas fresh meal similarly heated suffered no appreciable loss. When fresh meal was heated in air for $30 \mathrm{~h}$ at $85^{\circ}$, so that oxidation and reaction with the protein occurred simultaneously, the available lysine value fell by 10\% (Table 3 ). Temperatures higher than $85^{\circ}$ have been recorded in the interior of overheating piles of dried fish scrap (Meade, 1956).

'Bound' nitrogen in the lipids of heated herring meals. The chloroform-soluble ('purified') lipid extracted from the fresh fish meal used in our earlier work (Lea et al. I958) contained $0.9 \%$ nitrogen, of which part, perhaps about one-third, would be 
derived from phospholipids. After exposure of the meal to atmospheric oxygen for 4 months at $10^{\circ}$ the nitrogen content of this extract had risen to $1 \cdot 6 \%$.

The meal used in the present work, perhaps because it had been made from stale fish, already gave $\mathrm{I} \cdot 4 \%$ nitrogen in its chloroform-soluble lipids when freshly prepared, the value rising to $2.1 \%$ after storage of the meal in air for 3 months at $10^{\circ}$. The nitrogen contents of the crude chloroform-methanol extracts were higher, 2.5 and $2.7 \%$, respectively.

On heat treatment of the meals all four values increased, but the increase was only slight at temperatures up to $100^{\circ}$ (Fig. I C). At I I $5^{\circ}$, however, there was an appreciable rise, particularly with the oxidized meals, and at $130^{\circ}$ a very sharp rise occurred in the amounts of nitrogen present in the purified or, particularly, in the crude lipids extractable from the meal. Calculated on the same basis (percentage of the meal) for both fresh and pre-oxidized samples, meals heated at $100^{\circ}$ contained $3.9-4.6 \%$ available lysine and $0.34-0.42 \%$ chloroform-soluble nitrogen or $0.53-0.54 \%$ chloroform-methanol-soluble nitrogen. The same meals heated at $130^{\circ}$ contained only $\mathrm{I} \cdot 4-\mathrm{I} \cdot 6 \%$ available lysine but $0.8 \%$ chloroform-soluble nitrogen or $\mathrm{I} \cdot 6-\mathrm{I} \cdot 7 \%$ chloroform-methanol-soluble nitrogen. Since lysine contains rather less than $10 \%$ $\epsilon$-amino nitrogen the observed increases in chloroform-soluble nitrogen could more than account for the observed losses of available lysine.

However, the nature of the reactions leading to the appearance of these large quantities of nitrogenous material in the lipid extracts of the strongly heated meals is not yet known, nor can it be said whether these reactions are responsible for, or merely proceed parallel with, the extensive non-oxidative destruction of available lysine which occurs under the same temperature conditions (Fig. I $A-C$ ). These points are primarily of importance in connexion with the exceptionally severe losses of nutritive value which occur in badly overheated but not in normally processed or stored meals; they are being further investigated.

Protection by anti-oxidants. In herring meal no. 2, made from comparatively fresh fish, as little as $0.005 \%$ BHT (plus a similar quantity of citric acid) considerably delayed oxidation (Table 8). However, after storage for a year the oil in the stabilized meal showed evidence of considerable oxidation and it seemed advisable to try the effect of higher concentrations of anti-oxidant.

The meal (no. 3) used in the second series of experiments (Fig. 3) had been made from herring preserved with formaldehyde and it oxidized rather more rapidly than meal no. 2. It was not surprising, therefore, to find that $0.005 \% \mathrm{BHT}$ gave less protection than in the previous experiment, but $0.01 \% \mathrm{BHT}$ was considerably more effective and 0.025 or $0.05 \%$ still better. The difference between the effects of the last two concentrations was only very slight when measured by iodine value but more marked when measured by colour.

Citric acid tended to improve slightly the efficiency of the phenolic anti-oxidant, particularly during the earlier months of storage and when measured by iodine value, but the overall effect would seem too small to justify its use.

After I 2 months the better of the stabilized meals had deteriorated about $40 \%$ as much as the controls if the criterion was the iodine value of the extracted oil, but 
only about $10-20 \%$ as much if the criterion was its colour. Moreover, most of the change in the unstabilized meal had already occurred during the rst month (iodine value) or 3 months (colour) of storage.

In a third series of experiments, with meal no. 3 , the oxygen-absorption technique and $0.025 \%$ of the anti-oxidant (without citric acid), the degree of protection afforded by the anti-oxidants at $0.025 \%$ was again very marked (Fig. 4). After 8 months the stabilized meals have still absorbed only 4.4 (BHT), 3.7 (MBHQ), 2.0 (EMQ) and $\mathrm{I}^{\circ} \mathbf{9}$ (DPPD) $\mathrm{ml}$ oxygen, respectively, per $\mathrm{g}$, as compared with $6.7 \mathrm{ml}$ in I week and IO. I $\mathrm{ml}$ in 2 months by the untreated control. To date, therefore, the amino inhibitors DPPD and EMQ appear to be approximately equal and are both more effective than the phenols BHT and MBHQ. The last-named substance is considerably better than the dibutyl compound previously tested (Table 8 ) and appears to be at least as good as BHT, a compound which is already used in poultry feed to conserve vitamins $\mathrm{A}$ and $E$ and to give protection against encephalomalacia. DPPD, which has been widely used until recently for these purposes, is not now permitted in the U.S.A. EMQ has been incorporated on a limited scale in poultry feed and has recently been approved in the U.S.A. for addition to dehydrated forage crops at levels up to $0.015 \%$. BHT is a permitted anti-oxidant for edible fats in many countries, including the U.K. and the U.S.A.

The degree of protection afforded to herring meal by the anti-oxidants during the early stages of storage appeared to be better when measured in terms of the oxygen absorption of the meal (Fig. 4) or of the colour of the extracted oil (Fig. 3) than when the fall in the iodine value of the oil was the criterion (Fig. 3). This is probably because the iodine value is affected by oxidation-induced polymerization of the oil as well as by oxidation itself. The rate of change, whether measured by iodine value or by absorption of oxygen, was most rapid during the first few weeks.

Astrup (1958) has recently published findings showing a retarding effect of $0.03 \%$ $\mathrm{BHT}$ on the absorption of oxygen by herring meal: the protection afforded to his meal appears to have been considerably less than to either of ours.

Stabilization by heating. The effect of a preheating treatment in retarding oxidation of the meal during subsequent storage (Fig. 5) is of considerable interest, although the degree of stabilization achieved to date in these preliminary experiments is not sufficient to be of practical value. Slight improvements were obtained by heating the meal for $2 \mathrm{~h}$ (or even by storing it at $20^{\circ}$ for a long time) in the absence of oxygen, but the result was better when some oxygen was present. Such anti-oxidant effects have recently been demonstrated in foods and in model systems for the products of browning reactions between reducing sugars and amino compounds, and it is possible that the products of browning-type reactions, perhaps between fat-oxidation products and nitrogenous constituents of the meal, were involved in the present experiments. Oxidation-induced polymerization of the most reactive polyunsaturated fatty acids is another possibility.

We are now attempting to achieve a greater measure of stabilization without impairing the value of the meal as a protein supplement by adjustment of the variables in the system. 


\section{Nutritional changes}

The longer period of storage in the present trials has confirmed the overall impression from the earlier work (Lea et al. 1958) that, despite the rapid and extensive lipid oxidation that can occur in stored herring meal, there is only a slight drop in the value of the protein as a source of lysine. After storage for 12 months at $20^{\circ}$ in air there was a small fall in the amount of available lysine as determined chemically, amounting to $8 \%$ for untreated herring meal no. 3 and $4 \%$ for similar meal containing $0.025 \%$ BHT (Table 2). These values agree with the $9 \%$ loss during 12 months at $25^{\circ}$ found for herring meals $I$ and 2 in the earlier work (Lea et al. 1958). These small losses in 'available' lysine, however, produced no significant effects on growth of or feed conversion by chicks, as compared with an unoxidized control, when the meals were given at the $3.1 \%$ level as supplements to a diet in which lysine was the limiting factor.

The damaging effect of exposing herring meal to heat is brought out by the losses of available lysine which occurred when fresh meal in air or pre-oxidized meal in nitrogen was heated at $85^{\circ}$ (Table 3 ) or $100^{\circ}$ (Fig. I $A$ ). Much more marked still was the destructive effect, both on available lysine (Table 7 ) and on nutritive value (Table 9) of the overheating suffered by commercial meal during bulk storage. Laksesvela (1958) has also reported a low biological value and a $40 \%$ loss of available lysine in spontaneously heated herring meal.

The laboratory heating experiments showed that at sufficiently high temperatures severe losses of available lysine occur rapidly in the absence of oxygen, and that they are almost as great in fresh as in pre-oxidized meals. Obviously, fresh meal, like freeze-dried cod (Carpenter et al. 1957), can be damaged by severe heat in the absence of fat oxidation products, but the values in Fig. I $A$ show that, in the presence of these substances, damage occurs at lower temperatures which cause little or no loss of available lysine in their absence.

The experiments on the cod-muscle-propanal system indicate a likely mechanism for the destructive effect of fat oxidation products on lysine, but the low stoichiometric efficiency of the reaction, particularly at low temperatures, is in keeping with the very limited amount of damage to the protein usually found. Non-oxidative, hightemperature damage is likely to be accentuated by high moisture content (Carpenter et al. 1957), whereas oxidation of the oil is retarded by high moisture content (Lea et al. 1958; Astrup, 1958).

Longer feeding tests with both fresh and normally stored herring meals fed at higher levels are now being undertaken to ascertain whether toxic effects or nutritional deficiencies will appear under these conditions.

\section{Effects on palatability}

Only a few tasting tests with a small laboratory panel were made to look for possible effects of the oxidation of fish meal on its tainting properties, but the results were consistent. No 'fishy' or other 'off' flavour could be detected in the eggs or flesh of birds receiving $8 \%$ herring meal in the diet, and the result was the same whether 
the meal was in fresh condition or badly oxidized. Any slight suggestion of difference that there might have been was in the direction of the oxidized samples being better rather than worse. The amount of herring meal $(8 \%)$ used in these tests provided a total fish-oil content in the diet of approximately $1.0 \%$ ether or light-petroleum extract, or nearly $1 \cdot 4 \%$ chloroform-methanol extract.

Carlson, Potter, Matterson, Singsen, Gilpin, Redstrom \& Dawson (1957), in a recent comprehensive study of the effect of fish oil in the feed on the palatability of broilers, used a basal ration containing $5 \%$ menhaden fish meal, stated to contribute $0.5 \%$ menhaden oil to the diet. The method of determination was not stated: if a solvent giving incomplete extraction had been used up to $0.7 \%$ total fish lipid might have been present. This basal diet produced no tainting, nor did the addition of a further $0.5 \%$ of menhaden oil, making $1.0 \%$ in all. Addition of I or $2 \%$ of menhaden oil to the diet (total content $\mathrm{I} \cdot 5$ or $2 \cdot 5 \%$ ), however, caused a significant and progressive increase in the proportion of tasters reporting 'off' ('fishy') flavour. These 'off' flavours were said to be slightly less noticeable when the feed also contained $0.0125 \%$ DPPD ( $0.25 \%$ on the fish-meal basis).

The findings of Carlson et al. (1957) suggest that we were fairly near to the 'off' flavour threshold in our feeding experiment with fresh herring meal, and that any markedly greater tainting effect of the oxidized meal would have been detected had it existed. Recently Homb (1958) has also compared herring meals stored in different ways as supplements for bacon pigs (at a $10 \%$ level in the diet to $120 \mathrm{lb}$ and thereafter at $5 \%$ ): he detected no undesirable effects on flavour. It would seem that herring meal, whether fresh or stale, is not so dangerous in producing taints as is sometimes believed.

\section{SUMMARY}

I. Storage of herring meal $(6 \cdot 1 \%$ moisture $)$ in air for 12 months at $20^{\circ}$ caused only small losses of available lysine as determined chemically. These losses amounted to $8 \%$ for untreated meal and to $4 \%$ for similar meal containing $0.025 \% 2$,6-di-tbutyl-4-methylphenol.

2. When the meals were given at the $3 \cdot 1 \%$ level in a chick assay for lysine, these small losses in available lysine produced no significant effects on growth or efficiency of food conversion as compared with an unoxidized control meal.

3. When meal that had been stored in air for 3 months at $10^{\circ}$ and had lost $4 \%$ of its available lysine was heated for $30 \mathrm{~h}$ at $100^{\circ}$ in nitrogen a further loss of $12 \%$ occurred. Fresh meal similarly heated in nitrogen lost no available lysine; at $85^{\circ}$ in air $10 \%$ was lost.

4. Further evidence of a reaction between fat oxidation products and protein was found in the higher 'bound' lipid and thiobarbituric-acid values given by oxidized as compared with fresh herring meal. Propanal reacted rapidly with 'dry' fish muscle producing marked losses in 'available' lysine and in nutritive value.

5. A commercial sample of herring meal which overheated and darkened badly during bulk storage lost about $60 \%$ of its 'available' lysine and gave very poor results in the chick assay for lysine. Fresh and pre-oxidized meals heated in the laboratory 
for $30 \mathrm{~h}$ in the absence of oxygen also darkened and at $115^{\circ}$ lost $\mathrm{I} 9$ and $27 \%$, and at $130^{\circ} 67$ and $69 \%$, respectively, of their available lysine.

6. Several anti-oxidants, i.e. 2,6-di-t-butyl-4-methylphenol, monobutylhydroquinone and especially diphenyl-p-phenylenediamine and 6-ethoxy-2,2,4-trimethyl-I, 2-dihydroquinoline markedly reduced the rate of oxidation of the oil stored in herring meal. Citric acid showed only a weak synergistic effect with BHT. Preheating the meal before storage had some stabilizing effect.

7. Neither fresh nor oxidized ( 4 months in air at $20^{\circ}$ ) herring meal tainted the eggs or flesh of hens receiving it for up to 2 months as $8 \%$ of their diet.

\section{REFERENCES}

Astrup, H. (1958). Acta polyt., Stockh. (Chem. Ser.) 242, 58.

Bruno, D. \& Carpenter, K. J. (1957). Biochem. F. 67, I3 $P$.

Carlson, D., Potter, L. M., Matterson, L. D., Singsen, E. P., Gilpin, G. L., Redstrom, R. A. \& Dawson, E. H. (1957). Food Tech. 1x, 615.

Carpenter, K. J., Ellinger, G. M., Munro, M. I. \& Rolfe, E. J. (1957). Brit. F. Nutr. Ir, I62.

Carpenter, K. J., Jones, W. L. \& Mason, E. L. (1959). Biochem. F. 73, i IP.

Feuell, A. J. \& Skellon, J. H. (1953). Analyst, 78, I35.

Homb, T. (1958). Landbrukshøgskolens Institutt for Husdyrernaring og Fôringslaere. Sartrykk, no. 180, 1958.

Laksesvela, B. (1958). F. agric. Sci. 51, 164 .

Lea, C. H. (1947-8). $\mathscr{Y}$. Dairy Res. 15, 364 .

Lea, C. H. \& Hannan, R. S. (1949). Biochim. biophys. acta, 3, 313.

Lea, C. H., Parr, L. J. \& Carpenter, K. J. (1958). Brit. F. Nutr. r2, 297.

Maltby, J. G. \& Primavesi, G. R. (1949). Analyst, 74, 498.

Meade, T. L. (1956). Feedstuffs, 28, no. 20, p. 14.

Mohammad, A., Olcott, H. S. \& Fraenkel-Conrat, H. (1949). Arch. Biochem. 24, 270.

Narayan, K. A. \& Kummerow, F. A. (1958). F. Amer. Oil Chem. Soc. 35, 52.

Schwartz, M. G. \& Watts, B. M. (1957). Food Res. 22, 76.

Stander, G. H. \& Rowan, A. N. (1956). Fishing Industry Research Institute (S. Africa), loth Ann. Rep. p. 23.

Tappel, A. L. (1955). Arch. Biochem. Biophys. 54, 266.

Venolia, A. W. \& Tappel, A. L. (1958). F. Amer. Oil Chem. Soc. 35, 135.

Yu, T. C. \& Sinnhuber, R. O. (1957). Food Tech. II, 104.

Note added in proof. Since this paper was prepared C. H. J. van den Brock (1959) published an article on the spontaneous heating of fish meal (Food Manuf. 34, 349, $3^{87}$ ). 